\title{
Synthesis and Anion Binding Affinities of Novel Molecular Tweezers Based on Chenodeoxycholic Acid Bearing Different Lengths of Arm
}

\author{
Ki Soo Kim, Hyun-Seok Jang, and Hong-Seok Kim" \\ Department of Applied Chemistry, Kyungpook National University, Daegu 702-701, Korea. "E-mail: kimhs@knuac.kr \\ Received June 7, 2006
}

\begin{abstract}
Molecular tweezers based on chenodeoxycholic acid bearing difterent lengths of arm were synthesized and their anion binding affinities were evaluated by ${ }^{1} H \mathrm{NMR}$, isothermal calorimetric titration. and ESI mass spectrometry. Molecular tweezer 6 showed a high selectivity toward $\mathrm{II}_{2} \mathrm{PO}_{4}^{-}$over $\mathrm{Cl}^{-}, \mathrm{Br}^{-}, \mathrm{I}^{-}$, and $\mathrm{CII}_{3} \mathrm{CO}_{2}^{-}$ by 'II NMR titration, whereas the association constant for $\mathrm{F}^{-}$revealed the largest value as determined by ITC. The selectivity of 6 towards $\mathrm{F}^{-}$was about $10^{3}$ times higher than that of $\mathrm{Cl}$. $\mathrm{II}_{2} \mathrm{PO}_{4}^{-}$, and $\mathrm{CII}_{3} \mathrm{CO}_{2}^{-}$. ITC experiment of 6 with $\mathrm{F}^{-}$in a DMSO showed two binding modes; two sequential association constants $K_{1}=2.77$ $\times 10^{5} \mathrm{M}^{-1}$ and $K_{2}=8.68 \times 10^{6} \mathrm{M}^{-1}$ were found. These sequential bindings were confirmed by ESI mass spectrometry. $1: 1$ and $1: 2$ complexes of 6 and $\mathrm{F}^{-}$were found $\mathrm{at} \mathrm{m} / \mathrm{z} 868.08$ and 884.04 .
\end{abstract}

Key Words : Anion recognition, Molecular tweezer, Chenodeoxycholic acid, Fluoride ion

\section{Introduction}

Anion recognition by artificial neutral receptors has attracted increasing interest in recent years because of their significant importance and potential applications in biological, environmental, and supramolecular chemistry.' Because of their rigid frame, cholesterol and bile acid derivatives are ideal molecular scaffolds offering easy protocols of derivatization, and different preorganized structures, and exhibit ion-binding affinity. ${ }^{2}$ Davis et al. synthesized cryptand ${ }^{3}$ and tripodal anionophore." derived from cholic acid and used them for halide anion recognition. They found that tripodal anionophores form remarkably strong complexes with fluoride and chloride through cooperative hydrogen bonds in an organic solution. Among them 7,12-biscarbamoyl-3sulfonamide derivative shows a high affinity for fluoride ions in $\left.\mathrm{CDCl}_{3}\left(\mathrm{Ka}=1.54 \times 10^{4} \mathrm{M}^{-1}\right)\right)^{4}$ Maitra et al. also found that cholaphane from cholic acid shows moderate binding affinity toward fluoride ions $\left(K_{1}=10^{3} \mathrm{M}^{-1}, K_{2}=10^{2}\right.$ $\left.\mathrm{M}^{-1}\right)^{6}$

We designed and synthesized bile acid-based receptors, and found that the introduction of ion-recognizing moieties on the rigid steroid frames show binding affinities toward various ions. ${ }^{7-10}$ Chenodeoxycholic acid-based molecular tweezer 6, that has four urea hydrogen atoms, was found to bind with $\mathrm{Cl}^{-}\left(\mathrm{Ka}=2,750 \mathrm{M}^{-1}\right)$ and $\mathrm{H}_{2} \mathrm{PO}_{4}^{-}(\mathrm{Ka}=4,270$ $\left.\mathrm{M}^{-1}\right)$ in a $\mathrm{CDCl}_{3}$. ${ }^{7}$ Hyodeoxycholic acid-based tweezer bearing urea moieties at $3 \alpha$ and $6 \alpha$ positions exhibited a higher affinity toward $\mathrm{F}^{-}$than $\mathrm{Cl}^{-}, \mathrm{Br}^{-}$, and $\mathrm{H}_{3} \mathrm{PO}_{4}^{-9}$. Cholic acid-based tripodal receptor bearing same urea pendants at $3 \alpha, 7 \alpha$, and $12 \alpha$ positions was found to bind with $\mathrm{Cl}^{-}\left(K_{1}=\right.$ $7,640 \mathrm{M}^{-1}$ ) in a $\mathrm{CDCl}_{3}{ }^{10}$ Despite these results, more effective arrangements of binding sites is needed to better understand the nature of complex between the anion and neutral receptors. To investigate the relationship between receptor structures and anion affinities, Davis et al. have synthesized cholic acid-derived eight receptors with up to

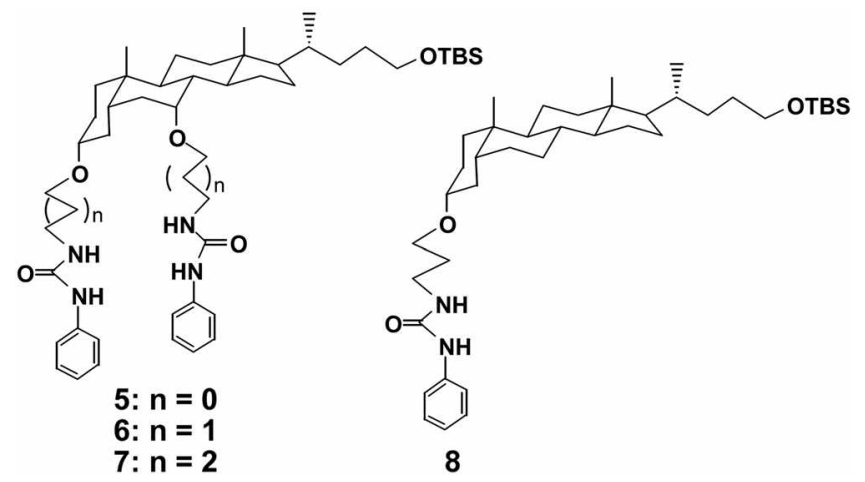

Figure 1

six H-bond donor centers. They found that anionophores bearing five or six $\mathrm{H}$-bond donors show high binding constants $\left(\mathrm{Ka}>10^{10} \mathrm{M}^{-1}\right)$ toward $\mathrm{Cl}^{-}$anions and that selectivities vary with receptor geometry; binding constants tend to increase in accordance with the number of $\mathrm{H}$-bond donor groups and also with their acidities." Therefore, the nature and geometry of receptors seem essential for steroid inclusion complex formation.

Continuing our efforts to develop a highly selective anion receptor, we designed neutral anion tweezers using chenodeoxycholic acid as a building block and urea as an anion recognizing pendant, and evaluated their anion binding affinities with a receptor bearing one urea pendant, as shown in Figure 1.

In this paper, we report that the synthesis of novel molecular tweezers based on chenodeoxycholic acid bearing different lengths of ureidopendant and their anion binding affinities in comparison with those of lithocholic acid-based receptor 8 .

\section{Results and Discussion}

Molecular recognition properties of receptor 6 that possess 


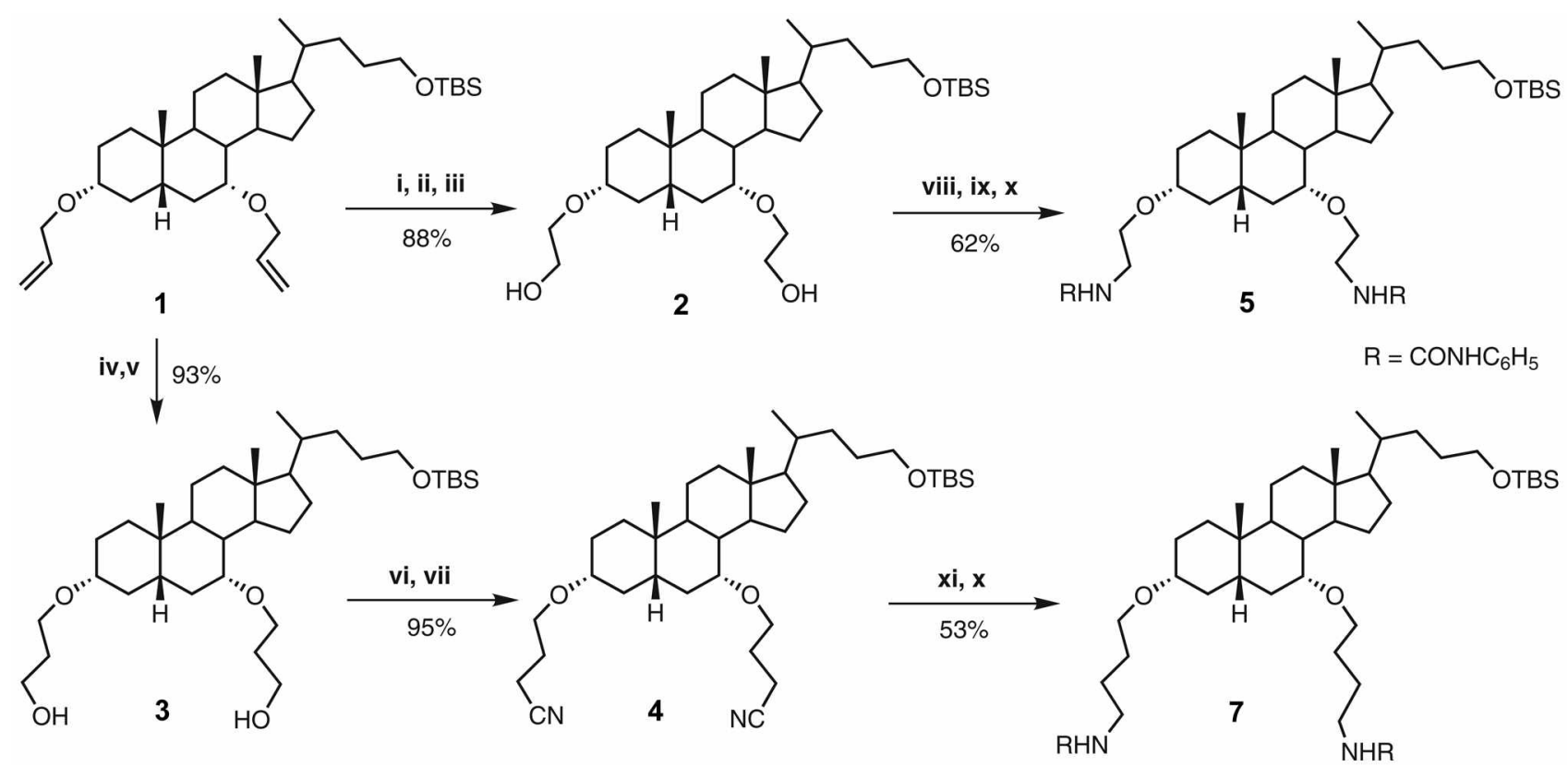

Scheme 1. i) $\mathrm{NMO}, \mathrm{OsO}_{4}(2.5 \%$ in $t-\mathrm{BuOH})$, citric acid, $t-\mathrm{BuOH} / \mathrm{H}_{2} \mathrm{O}\left(1\right.$ : I); ii) $\mathrm{NalO}$, THF/ $\mathrm{H}_{2} \mathrm{O}(10: 1)$;ii) $\mathrm{NaBH}$, $\mathrm{EtOH}$; iv) $9-\mathrm{BBN}$, THF; v) $\mathrm{NaOH} / \mathrm{H}_{2} \mathrm{O}_{2} ;$ vi) $\mathrm{MsCl}, \mathrm{Et}_{3} \mathrm{~N}, \mathrm{CH}_{2} \mathrm{Cl}_{2}$; vii) $\mathrm{NaCN}$, DMSO; viii) DEAD, $\mathrm{PPh}_{3}$, phthalimide, THF; ix) $\mathrm{H}_{2} \mathrm{NNH}_{2} \mathrm{H}_{2} \mathrm{O}, \mathrm{EtOH}$; $\mathrm{x}$ ) $\left.\mathrm{C}_{6} \mathrm{H}_{3} \mathrm{NCO}_{2} \mathrm{CH}_{3} \mathrm{Cl} ; \mathrm{xi}\right) \mathrm{LiAlH}_{4}, \mathrm{THF}$.

two ureidopendants at $3 \alpha$ and $7 \alpha$ linked by three methylene units have been investigated previously. ${ }^{7}$ To evaluate the effect of the linker length in anion binding affinity, two receptors that possess different length of ureidopendants at 3 and 7 positions in the steroid were designed. Receptor 5 was linked by two methylene units, and 7 was linked by four methylene units.

The synthesis of the new molecular tweezers 5 and 7 is described in Scheme 1. Commercially available chenodeoxychoilc acid was converted into the corresponding diallyl ether 1 , which was used in the synthesis of 6 ? Dihydroxylation of 1 with $\mathrm{OsO}_{4}$, followed by $\mathrm{NaIO}_{4}$ cleavage, and $\mathrm{NaBH}_{4}$ reduction provided 2 as a white solid in a $88 \%$ yield. Under these sequential steps, double bonds were oxidatively cleaved. Receptor 5 was prepared by three sequential procedures in $62 \%$ yield; treatment of 2 with phthalimide, triphenylphosphine, and DEAD, followed by subsequent hydrazinolysis with hydrazine hydrate, and coupling of the resulting amine with phenyl isocyanate. One carbon elongation of 3 , which was obtained by hydroboration of $\mathbf{1}$, was carried out via mesylation, cyanation, and reduction sequentially. Mesylation of $\mathbf{3}$ with methanesulfonyl chloride in the presence of triethylamine, followed by cyanation with $\mathrm{NaCN}$ in DMSO gave 4 in a $95 \%$ yield. Reduction of the latter with $\mathrm{LiAlH}_{4}$ in THF provided amine and subsequent coupling with phenyl isocyanate in dry $\mathrm{CHCl}_{3}$ at room temperature produced $7 \mathrm{in}$ a $53 \%$ yield. The structures of the obtained compounds were characterized by IR, ${ }^{1} \mathrm{H},{ }^{13} \mathrm{C}$ NMR, mass spectrometry, and elemental analyses.

Initial anion binding affinities of receptors 5,6 , and 7 were investigated by standard ' $\mathrm{H} N \mathrm{NR}$ titrations in the presence of $\mathrm{Cl}^{-}, \mathrm{Br}^{-}, \mathrm{I}^{-}, \mathrm{H}_{2} \mathrm{PO}_{4}^{-}$, and $\mathrm{CH}_{3} \mathrm{CO}_{2}^{-}$anions as their tetrabutylammonium salts (TBA) in a $\mathrm{CDCl}_{3}$ solution. ${ }^{12}$ The

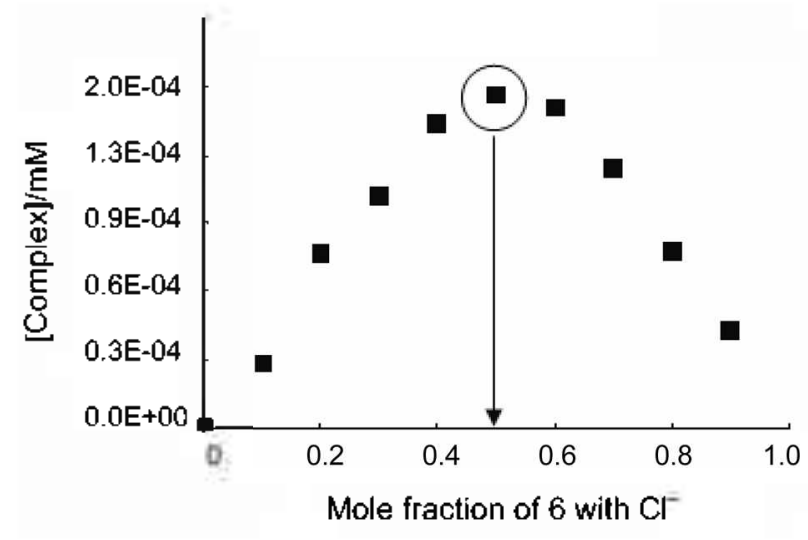

Figure 2. Job plot of 6 with TB $A C l$.

addition of equimolar TBACl to a solution of 6 caused significant downfield shifts of both the phenyl and alkyl NH signals by up to $\Delta \delta=1.79$ and $1.08 \mathrm{ppm}$, indicating that anion binding took place in the vicinity of urea. ${ }^{7} \mathrm{~A}$ job plot of 6 with $\mathrm{TBACl}$ indicated that 6 formed a $1: 1$ complex with $\mathrm{Cl}^{-}$(Figure 2). ${ }^{13}$

As summarized in Table 1, the association constants of 6 and other receptors were obtained by a nonlinear curve fitting EQ-NMR program. ${ }^{14}$ Molecular tweezers 5, 6 and 7 bind all anions used irrespective of their shape, and all association constants $K a$ lie between $10^{2}$ and $10^{3} \mathrm{M}^{-1}$. The association constants of 5 , linked by two methylene units, showed $840,260,220,1,380$, and $390 \mathrm{M}^{-1}$ (errors $\leq 15 \%$ ) for the binding of $\mathrm{Cl}, \mathrm{Br}, \mathrm{I}^{-}, \mathrm{H}_{2} \mathrm{PO}_{4}^{-}$, and $\mathrm{CH}_{3} \mathrm{CO}_{2}^{-}$, respectively. The association constants of 6 , linked by three methylene units, revealed $2,750,1,200,260,4,270$, and 690 $\mathrm{M}^{-1}$ for the binding of $\mathrm{Cl}, \mathrm{Br}^{-}, \mathrm{I}^{-}, \mathrm{H}_{2} \mathrm{PO}_{4}^{-}$, and $\mathrm{CH}_{3} \mathrm{CO}_{2}^{-}$, 
Table 1. Association constants $\left(\mathrm{M}^{-1}\right)$ of receptors with various anions obtained from ' $\mathrm{H}$ NMR titration

\begin{tabular}{cccccc}
\hline \multirow{2}{*}{ Receptor } & \multicolumn{5}{c}{ Anion, $\mathrm{Ka}^{4}$} \\
\cline { 2 - 6 } & $\mathrm{Cl}^{-}$ & $\mathrm{Br}^{-}$ & $\mathrm{I}^{-}$ & $\mathrm{H}_{2} \mathrm{PO}_{4}^{-}$ & $\mathrm{CH}_{7} \mathrm{CO}_{2}^{-}$ \\
\hline $\mathbf{5}$ & 840 & 260 & 220 & 1,380 & 390 \\
6 & $2,750^{b}$ & $1,200^{b}$ & $260^{b}$ & $4,270^{b}$ & $690^{b}$ \\
7 & 1,600 & 1,280 & 710 & 2,270 & 2,400 \\
8 & $1,550^{\circ}$ & $430^{\circ}$ & $170^{\circ}$ & $510^{\circ}$ & - \\
\hline
\end{tabular}

${ }^{a}$ Determined in $\mathrm{CDCl}_{3}$, at $25^{\circ} \mathrm{C},[\mathrm{H}]_{\mathrm{o}}=4.5 \times 10^{-3} \mathrm{M}$. Errors estimated to be $\leq 15 \%$. "Values from ref." Values from ref.

respectively. 6 exhibited the largest association constant $(\mathrm{Ka}$ $=4,270 \mathrm{M}^{-1}$ ) for $\mathrm{H}_{2} \mathrm{PO}_{4}^{-}$. This comes from complexation of oxyanions of tetradentate, $\mathrm{H}_{2} \mathrm{PO}_{4}^{-}$, which represents the effect of cooperative hydrogen bonding between $\mathrm{N}-\mathrm{H}$ and $\mathrm{O}^{-}$. The proposed geometry of the receptor-anion interaction between 6 and the phosphate ion is explained by molecular mechanic calculations that show that phosphate ions bound within the molecular cavity in a strong hydrogen bond to $\mathrm{N}-$ $\mathrm{H}$ protons tetrahedral mode (estimate distance of $\mathrm{N}-\mathrm{H}{ }^{\cdots} \mathrm{O}^{-}$ $=1.60-1.73 \AA) .{ }^{10} 6$ also revealed the highest association constant for $\mathrm{Cl}^{-}$ions $(\mathrm{Ka}=2,750)$ as compared to those of other receptors; $5\left(\mathrm{Ka}=840 \mathrm{M}^{-1}\right)$ and $7\left(\mathrm{Ka}=1,600 \mathrm{M}^{-1}\right)$. The association constants of 7 , linked by four methylene units, showed $1,600,1,280,710,2,270$ and $2,400 \mathrm{M}^{-1}$ for the binding of $\mathrm{Cl}^{-}, \mathrm{Br}^{-}, \mathrm{I}^{-}, \mathrm{H}_{2} \mathrm{PO}_{4}^{-}$, and $\mathrm{CH}_{3} \mathrm{CO}_{2}^{-}$, respectively. 7 exhibited the highest association constants for $\mathrm{Br}^{-}, \mathrm{I}^{-}$, and $\mathrm{CH}_{3} \mathrm{CO}_{2}{ }^{-}$ions among the receptors tested. These results implicate that the liker length (number of methylene units) affect the binding modes through hydrogen bonding interactions with halides such as $\mathrm{Br}^{-}$and $\mathrm{I}^{-}$and $\mathrm{N}-\mathrm{H}$ protons of receptor.
Table 2. Association constants $\left(\mathrm{M}^{-1}\right)$ of receptors with TBAF obtained from ITC

\begin{tabular}{cccc}
\hline Receptor & $\mathbf{5}$ & $\mathbf{6}$ & $\mathbf{7}$ \\
\hline$K_{1}^{0}$ & $4.09 \times 10^{3}$ & $2.77 \times 10^{5}$ & $1.40 \times 10^{3}$ \\
$K_{2}^{0}$ & $4.55 \times 10^{4}$ & $8.68 \times 10^{6}$ & $2.00 \times 10^{\mathrm{t}}$ \\
\hline
\end{tabular}

Determined in DMSO, at $25^{\circ} \mathrm{C},[\mathrm{H}]_{\mathrm{c}}=1.0 \times 10^{-3} \mathrm{M},[\mathrm{G}]_{\mathrm{c}}=1.5 \times 10^{-4}$ M. Etrots estimaled to be $\leq 15 \%$.

The association constants of 8 bearing one urea pendant showed $1,500,430,170$, and $510 \mathrm{M}^{-1}$ for the binding of $\mathrm{Cl}^{-}$, $\mathrm{Br}^{-}, \mathrm{I}^{-}$, and $\mathrm{H}_{2} \mathrm{PO}_{4}^{-}$, respectively. It is obvious that the number of ureido pendant influences anion binding. ${ }^{10}$ For halides and $\mathrm{H}_{2} \mathrm{PO}_{4}{ }^{-}, 6$, possesses two urea pendants, exhibits much higher binding ability than 8 , bears only one urea pendant.

In contrast to the above results, measurement of the association constant of 6 for $\mathrm{F}^{-}$ions by ${ }^{1} \mathrm{H}$ NMR titration was unsuccessful. This may be due to the formation of a very strong complex between 6 and $\mathrm{F}^{-}$. Further insights regarding the nature of the complex between 6 and $\mathrm{F}^{-}$ions were obtained from the isothemal titration calorimetry (ITC) experiment of 6 with TBAF in a DMSO solution.

Significantly, 6 revealed two kinds of binding modes. Two sequential association constants $K_{1}=2.77 \times 10^{\circ} \mathrm{M}$ and $K_{2}$ $=8.68 \times 10^{6} \mathrm{M}^{-1}$ were found, and these values were the highest association constants when compared to those of 5 and 7 as presented in Table 2. Reverse titration of $\mathrm{F}^{-}$with 6 in a DMSO solution revealed similar two sequential association constants $K_{1}=1.48 \times 10^{4} \mathrm{M}^{-1}$ and $K_{2}=1.21 \times 10^{9} \mathrm{M}^{-1}$. These results suggest that addition of $\mathrm{F}^{-}$to 6 forms a $1: 1$ complex and becomes $I: 2$ with increasing concentration of $\mathrm{F}^{-}$. Similarly, the receptors 5 and 7 also revealed two

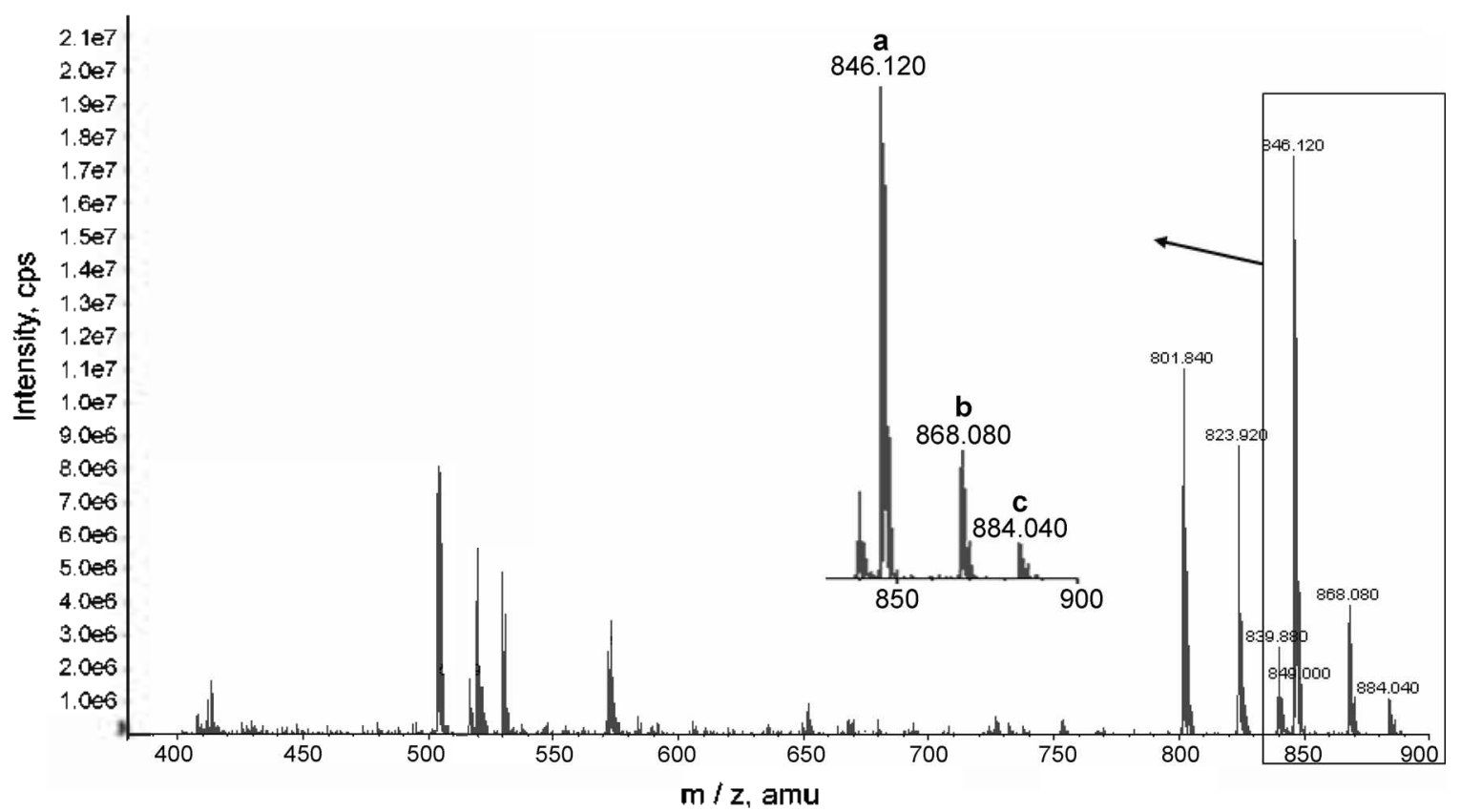

Figure 3. ESI mass spectrum of complexes between 6 and $\mathrm{F}^{-}$as TBA salt in aqueous methanol. $\mathrm{a}, 846.12\left[6+\mathrm{H}^{-}: \mathbf{b}, 868.08\left[6+\mathrm{F}^{-}+4 \mathrm{H}^{-}\right.\right.$; c, $884.04\left[6+2 \mathrm{~F}^{-}+\mathrm{HI}^{\mathrm{t}}\right.$. 
binding modes with $\mathrm{F}^{-}$, but their association constants were smaller than those of 6 . These results indicate that linker length of the pendants in the receptors affect the binding mode through hydrogen bonding interaction with receptor and anions.

It is noteworthy that during the course of ' $\mathrm{H} N \mathrm{NM}$ and ITC experiments of receptors with TBAF, no significant removal of TBS group from receptors was found by TLC. Receptors were recovered after binding experiments quantitatively by chromatographic separation.

Further support for the observed $1: 2$ complexation of $6-$ $\mathbf{F}^{-}$was obtained by electrospray ionization (ESI) mass spectrometry, as shown in Figure 3. The ESI mass spectrum of an equimolar solution of the 6 and TBAF in aqueous methanol revealed a peak corresponding to the $1: 1$ complex; $\left[6+\mathrm{F}^{-}+4 \mathrm{H}\right]^{+}, \mathrm{m} / \mathrm{z}=868.08$. In addition, a $1: 2$ complex, $\left[6+2 \mathrm{~F}^{-}+\mathrm{H}\right]^{+}$, at $\mathrm{m} / \mathrm{z}=884.04$ was also observed. The observation of a $1: 2$ complex peak further supports the existence of ionic interaction between the $1: 1$ inclusion complex and $\mathrm{F}^{-}$.

\section{Conclusion}

This study examined the binding properties of new chenodoxycholic acid-based molecular tweezers 5,6 , and 7 for various anions using ' $\mathrm{H}$ NMR, ITC, and ESI mass analysis. Among the tweezers, 6 exhibited a pronounced affinity toward anions. The best binding was observed with $\mathrm{F}^{-}$anions. The selectivity of 6 for $\mathrm{F}^{-}$was about $10^{3}$ times higher than that of $\mathrm{Cl}^{-}, \mathrm{H}_{2} \mathrm{PO}_{4}{ }^{-}$, and $\mathrm{CH}_{3} \mathrm{CO}_{2}{ }^{-} .6$ formed 1 : 1 to $1: 2$ complexes with $\mathrm{F}^{-}$sequentially upon increasing $\mathrm{F}^{-}$ ions; this result was confirmed by an ITC experiment and ESI mass analysis. The size of anion and the linker length of the pendants in the receptors determine binding selectivity.

\section{Experimental Section}

General experimental procedures for melting points, FTIR spectra, mass spectra, high resolution MS, and elemental analyses have been described previously. ${ }^{15} \mathrm{H}$ and ${ }^{13} \mathrm{C} \mathrm{NMR}$ spectra were recorded on a Bruker AM- 400 spectrometer. ' $\mathrm{H}$ and ${ }^{13} \mathrm{C}$ NMR assignments were made by comparison with the spectra of similar steroids. ${ }^{7} \mathrm{NMR}$ titrations were run at $45 \mathrm{mM}$ concentrations, with aliquots of a $0.25 \mathrm{M}(n \mathrm{Bu})_{4} \mathrm{~N}^{+} \mathrm{X}^{-}$ salts solution added. Isothemal titration calorimetric (ITC) measurements were performed using an Omega titration microcalorimeter. A $15 \mathrm{mM}$ solution of TBA salt in 40 times $(5 \mathrm{~mL}$ injection) was added to a $1 \mathrm{mM}$ receptor solution $(1.8$ $\mathrm{mL}$ ) in a calorimetric cell. The ESI mass spectrum was determined as described in the literature. ${ }^{16}$ TLC analyses were carried out on a plate precoated with $0.2 \mathrm{~mm}$ HPTLC silica gel 60 (E. Merck, Darmstadt); substances were visualized by spraying with $5 \%$ ammonium molybdate in $10 \% \mathrm{H}_{2} \mathrm{SO}_{4}$ followed by heating. Flash column chromatography was performed with Merck silica gel 60 (70-230 mesh). Reactions were carried out under an argon atmosphere, and the solutions were washed with brine and dried over anhydrous sodium sulfate. Compounds 1, 3, 6 and 8 were prepared as described in literatures. ${ }^{7.10}$

24-tert-Butyldimethylsilyloxy-3 $\alpha, 7 \alpha$-di(2'-hydroxyethoxy)-5 $\beta$-cholane (2). $\mathrm{OsO}_{4}(3.2 \mathrm{~mL}, 2.5 \%$ in $t-\mathrm{BuOH})$ was added slowly to a solution of $1(300 \mathrm{mg}, 0.52 \mathrm{mmol})$ and citric acid $(75 \mathrm{mg}, 0.39 \mathrm{mmol})$ in $t-\mathrm{BuOH} / \mathrm{H}_{2} \mathrm{O}(3 \mathrm{~mL}$, v/v 1 : 1) at room temperature. After $5 \mathrm{~min}, 50 \%$ aqueous $4-$ methylmorpholine $N$-oxide $(0.24 \mathrm{~mL}, 2.2 \mathrm{mmol})$ was added to the mixture and stirred for $24 \mathrm{~h}$. The mixture was extracted with ethyl acetate, washed, dried, and evaporated. The residue was reacted with $\mathrm{NaIO}_{4}(492 \mathrm{mg}, 2.30 \mathrm{mmol})$ in $\mathrm{THF} / \mathrm{H}_{2} \mathrm{O}(25 \mathrm{~mL}, \mathrm{v} / \mathrm{v} 10: 1)$ for $1 \mathrm{~h}$, and extracted with ethyl acetate, dried, and concentrated. The residue was reacted with $\mathrm{NaBH}_{4}(80 \mathrm{mg}, 2.11 \mathrm{mmol})$ in a ethanol $(60$ $\mathrm{mL}$ ) for $4 \mathrm{~h}$ at room temperature. Then the residue was extracted with dichloromethane, dried, and evaporated. The residue was purified by column chromatography (elution with EtOAc : hexane $2: 1$ ) to give $2\left(265 \mathrm{mg}, 88 \%\right.$ ). TLC $\mathrm{R}_{\mathrm{j}}$. 0.32 (EtOAc : hexane $2: 1$ ); m.p. $88-90^{\circ} \mathrm{C}\left(\mathrm{CH}_{2} \mathrm{Cl}_{2-}\right.$ hexane); IR $(\mathrm{KBr}) 3430,2932,2253,2126,1658,1052$, $1027,1007,825,762,627 \mathrm{~cm}^{-1}$; 'H NMR $\left(\mathrm{CDCl}_{3}\right) \delta 4.46$ $(\mathrm{bs}, 2 \mathrm{H},-\mathrm{OH}), 3.52(\mathrm{t}, J=5.5 \mathrm{~Hz}, 3 \mathrm{H}), 3.36(\mathrm{~m}, 3 \mathrm{H}), 3.25(\mathrm{~s}$, $1 \mathrm{H}), 3.08(\mathrm{~m}, 2 \mathrm{H}), 0.86\left(\mathrm{~d}, J=6.5 \mathrm{~Hz}, 21-\mathrm{CH}_{3}\right), 0.84(\mathrm{~s}$, $12 \mathrm{H}, 19-\mathrm{CH}_{3}$ and $\left.-\mathrm{SiC}\left(\mathrm{CH}_{3}\right)_{3}\right), 0.59\left(\mathrm{~s}, 3 \mathrm{H}, 18-\mathrm{CH}_{3}\right),-0.01$ $\left(\mathrm{s}, 6 \mathrm{H},-\mathrm{Si}\left(\mathrm{CH}_{3}\right)_{2}\right) ;{ }^{13} \mathrm{C} \mathrm{NMR}\left(\mathrm{CDCl}_{3}\right) \delta 77.5,74.5,68.7$, $67.7,61.7,59.5,59.4,54.6,48.6,40.8,40.1,33.9,33.7,33.6$, $32.1,30.6,30.4,27.8 .27 .2,26.7,25.8,24.7,24.6,22.0,21.5$, $19.3,17.4,16.7,10.4,-6.5$; HR-FAB (EI) calcd. for $\mathrm{C}_{34} \mathrm{H}_{64} \mathrm{O}_{5} \mathrm{Si}: 580.4523$, Found: 580.4579 .

24-tert-Butyldimethylsilyloxy-3 $\alpha, 7 \alpha$-di(3'-cyanopropanoxy)-5 $\beta$-cholane (4). Compound $3(500 \mathrm{mg}, 0.82 \mathrm{mmol}$ ) was treated with methanesulfonyl chloride $(0.20 \mathrm{~mL}, 2.49$ mmol) and triethylamine $(0.48 \mathrm{~mL}, 3.45 \mathrm{mmol})$ in a dry $\mathrm{CH}_{2} \mathrm{Cl}_{2}(30 \mathrm{~mL})$ in an ice bath for $10 \mathrm{~min}$. After the reaction was completed, it was extracted with $\mathrm{CH}_{2} \mathrm{Cl}_{2}$, dried and concentrated. Without further purification, the residue was reacted with $\mathrm{NaCN}(231 \mathrm{mg}, 4.72 \mathrm{mmol})$ in a DMSO (30 $\mathrm{mL}$ ) at $80^{\circ} \mathrm{C}$ for $30 \mathrm{~min}$. The mixture was extracted with $\mathrm{CH}_{2} \mathrm{Cl}_{2}$, dried, and concentrated. The residue was purified by column chromatography (elution with EtOAc : hexane 1 : 2) to give $4(448 \mathrm{mg}, 95 \%)$ as an oil. TLC $\mathrm{R}_{r} 0.66$ (EtOAc : hexane $1: 2$ ); IR (neat) $3484,2933,2859,2249,1470,1365$, $1253,1105,836,776,619 \mathrm{~cm}^{-1} ;{ }^{1} \mathrm{H} \mathrm{NMR}\left(\mathrm{CDCl}_{3}\right) \delta 3.69$ $(\mathrm{m}, 1 \mathrm{H}), 3.52\left(\mathrm{~m}, 4 \mathrm{H},-\mathrm{OCH}_{2} \mathrm{CH}_{2} \mathrm{CH}_{2} \mathrm{CN}\right), 3.25(\mathrm{~s}, 1 \mathrm{H}, 7 \beta$ $\mathrm{H}), 3.12(\mathrm{~m}, 1 \mathrm{H}), 3.04(\mathrm{~m}, 1 \mathrm{H}, 3 \beta-\mathrm{H}), 2.43(\mathrm{~m}, 4 \mathrm{H}$, $\left.-\mathrm{OCH}_{2} \mathrm{CH}_{2} \mathrm{CH}_{2} \mathrm{CN}\right), 0.87\left(\mathrm{~d}, J=6.5 \mathrm{~Hz}, 3 \mathrm{H}, 21-\mathrm{CH}_{3}\right), 0.85$ (s, $12 \mathrm{H}, 19-\mathrm{CH}_{3}$ and $\left.-\mathrm{SiC}\left(\mathrm{CH}_{3}\right)_{3}\right), 0.58\left(\mathrm{~s}, 3 \mathrm{H}, 18-\mathrm{CH}_{3}\right)$, $-0.02\left(\mathrm{~s}, 6 \mathrm{H},-\mathrm{Si}\left(\mathrm{CH}_{3}\right)_{2}\right) ;{ }^{13} \mathrm{C} \mathrm{NMR}\left(\mathrm{CDCl}_{3}\right) \delta 121.6,121.5$, $79.8,77.1,67.1,66.2,64.4,62.9,57.1,51.3,43.5,42.6,36.3$, $36.2,36.1,35.1,33.9,32.5,31.8,29.4,29.0,28.0,27.3,27.2$, $27.1,25.0,24.1,20.9,19.3,15.1,14.9,13.1,-3.9$; HR-FAB (EI) calcd. for $\mathrm{C}_{38} \mathrm{H}_{66} \mathrm{~N}_{2} \mathrm{O}_{3} \mathrm{Si}: 626.4843$, Found: 627.0255 $(\mathrm{M}+\mathrm{H})^{+}$.

Molecular tweezer 5. Phthalimide $(640 \mathrm{mg}, 4.35 \mathrm{mmol})$, $\mathrm{PPh}_{3}(1.14 \mathrm{~g}, 4.35 \mathrm{mmol})$, and diethyl azodicarboxylate $(0.69 \mathrm{~mL}, 4.35 \mathrm{mmol})$ was added to a solution of $2(500 \mathrm{mg}$, $0.86 \mathrm{mmol})$ in a dry $\mathrm{THF}(50 \mathrm{~mL})$ and stirred at room 
temperature for $12 \mathrm{~h}$. After the reaction was completed, it was extracted with ethyl acetate, dried, and concentrated. The residue was refluxed with $\mathrm{H}_{2} \mathrm{NNH}_{2} \cdot \mathrm{H}_{2} \mathrm{O}(0.20 \mathrm{~mL}, 4.20$ $\mathrm{mmol}$ ) in a ethanol $(200 \mathrm{~mL})$ for $24 \mathrm{~h}$. After the solvent was removed, the mixture was treated with $20 \% \mathrm{NaOH}(10 \mathrm{~mL})$ and extracted with ethyl acetate, dried, and concentrated. Without further purification, the residue was reacted with phenyl isocyanate $(0.39 \mathrm{~mL}, 3.51 \mathrm{mmol})$ in a $\mathrm{CHCl}_{3}(20$ $\mathrm{mL}$ ) for $1 \mathrm{~h}$. After the solvent was removed, it was extracted with ethyl acetate, dried, and concentrated. The residue was purified by column chromatography (elution with EtOAc : hexane $1: 2$ ) to give $5(435 \mathrm{mg}, 62 \%)$. TLC R 0.48 (EtOAc : hexane $1: 1)$; m.p. $98-100^{\circ} \mathrm{C}\left(\mathrm{CH}_{2} \mathrm{Cl}_{2}\right.$-hexane); $\mathrm{R}(\mathrm{KBr})$ $3435,2932,2859,1650,1599,1555,1100,756 \mathrm{~cm}^{-1}$; 'H NMR (DMSO-d $) \delta 8.51(\mathrm{~s}, 1 \mathrm{H}), 8.42(\mathrm{~s}, 1 \mathrm{H}), 7.35(\mathrm{~d}, J=$ $7.5 \mathrm{~Hz}, 4 \mathrm{H}$ ), 7.17 (dd, $J=14.3,7.5 \mathrm{~Hz}, 4 \mathrm{H}$ ), 6.85 (dd, $J=$ $13.0,7.0 \mathrm{~Hz}, 4 \mathrm{H}), 6.09(\mathrm{t}, J=6.0 \mathrm{~Hz}, 1 \mathrm{H}), 6.05(\mathrm{t}, J=6.0$ $\mathrm{Hz}, 1 \mathrm{H}), 3.57-3.40(\mathrm{~m}, 5 \mathrm{H}), 3.22-3.05(\mathrm{~m}, 6 \mathrm{H}), 0.84$ (bs, $15 \mathrm{H}, 21-\mathrm{CH}_{3}$ and $\left.19-\mathrm{CH}_{3},-\mathrm{SiC}\left(\mathrm{CH}_{3}\right)_{3}\right), 0.56(\mathrm{~s}, 3 \mathrm{H}, 18-$ $\left.\mathrm{CH}_{3}\right),-0.01\left(\mathrm{~s}, 6 \mathrm{H},-\mathrm{Si}\left(\mathrm{CH}_{3}\right)_{2}\right) ;{ }^{13} \mathrm{C} \mathrm{NMR}\left(\mathrm{DMSO}-d_{6}\right) \delta$ $155.5,155.4,140.9,140.8,128.9,128.9,121.3,117.9,75.3$, $75.2,67.8,66.8,63.2,55.9,49.9,42.3,41.5,41.5,39.2,38.7$, $35.4,35.2,29.4,28.8,28.4,27.3,26.1,29.4,27.3,26.1,22.9$, $20.7,18.9,18.2,11.8,-4.9$; Anal. calcd. for $\mathrm{C}_{48} \mathrm{H}_{76} \mathrm{~N}_{4} \mathrm{O}_{5} \mathrm{Si}$ : C, $70.55 ; \mathrm{H}, 9.37 ; \mathrm{N}, 6.86$; Found: C, 70.32; H, 9.31 ; N, 6.61.

Molecular tweezer $7 . \mathrm{LiAlH}_{4}(45 \mathrm{mg}, 1.18 \mathrm{mmol}$ ) was added to a solution of $4(500 \mathrm{mg}, 0.80 \mathrm{mmol})$ in a dry THF $(10 \mathrm{~mL})$ and stirred at room temperature for $1 \mathrm{~h}$. After the reaction was completed, it was quenched with ethyl acetate and saturated $\mathrm{Na}_{2} \mathrm{SO}_{4}$ solution, and the precipitant was removed by filtration. The organic layer was dried and concentrated. Without further purification, the residue was reacted with phenyl isocyanate $(0.09 \mathrm{~mL}, 0.87 \mathrm{mmol})$ in a $\mathrm{CHCl}_{3}(20 \mathrm{~mL})$ for $1 \mathrm{~h}$. After the solvent was removed, it was extracted with ethyl acetate, dried, and concentrated. The residue was purified by column chromatography (elution with EtOAc : hexane $1: 1)$ to give $7(370 \mathrm{mg}, 53 \%)$. TLC $\mathrm{R}_{\mathrm{r}} 0.51$ (EtOAc : hexane 1 : 1); m.p. 107-109 ${ }^{\circ} \mathrm{C}$ $\left(\mathrm{CH}_{2} \mathrm{Cl}_{2}\right.$ : hexane); IR (KBr) 3436, 2930, 2252, 2126, 1659, $1550,1499,1053,1027,1007,824,762,627 \mathrm{~cm}^{-1}$ : 'H NMR $\left(\mathrm{CDCl}_{3}\right) \delta 8.35(\mathrm{~s}, 2 \mathrm{H}), 7.37(\mathrm{~d}, J=7.5 \mathrm{~Hz}, 4 \mathrm{H}), 7.18(\mathrm{~m}$, $4 \mathrm{H}), 6.85(\mathrm{~m}, 4 \mathrm{H}), 6.09(\mathrm{t}, J=4.5 \mathrm{~Hz}, 2 \mathrm{H}), 3.59(\mathrm{~m}, 4 \mathrm{H})$, $3.49(\mathrm{t}, J=5.5 \mathrm{~Hz}, 2 \mathrm{H}), 3.22(\mathrm{~s}, 1 \mathrm{H}), 3.07(\mathrm{~m}, 6 \mathrm{H}), 2.50(\mathrm{~s}$, $1 \mathrm{H}), 0.84\left(\mathrm{bs}, 15 \mathrm{H}, 21-\mathrm{CH}_{3}, 19-\mathrm{CH}_{3}\right.$ and $\left.-\mathrm{SiC}\left(\mathrm{CH}_{3}\right)_{3}\right), 0.59$ $\left(\mathrm{s}, 3 \mathrm{H}, 18-\mathrm{CH}_{3}\right),-0.02\left(\mathrm{~s}, 6 \mathrm{H},-\mathrm{Si}\left(\mathrm{CH}_{3}\right)_{2}\right) ;{ }^{13} \mathrm{C} \mathrm{NMR}$
$\left(\mathrm{CDCl}_{3}\right) \delta 155.5,140.9,128.9,128.8,121.2,121.1,117.9$ $117.8,78.6,75.7,67.8,67.4,66.9,63.2,56.1,50.3,42.3$, $41,5,39.2,39.1,35.4,35.2,35.1,33.6,31.8,29.3,28.6,28.1$, 27.6, 27.5, 27.1, 26.1, 25.5, 23.7, 23.0, 20.7, 18.8, 18.2, 11.8, 4.9; Anal. calcd. for $\mathrm{C}_{52} \mathrm{H}_{84} \mathrm{~N}_{4} \mathrm{O}_{5} \mathrm{Si}: \mathrm{C}, 71.51 ; \mathrm{H}, 9.69 ; \mathrm{N}$, 6.42; Found: C, 71.18; H, 9.79; N, 6.20.

Acknowledgments. This work was supported by grant from the KOSEF (R05-2001-000-00227-0) and the BK 21 program.

\section{References}

I. (a) Gale, P. A. Coord. Chem, Rev: 2003, 240, 17-55. (b) Beer, P. D.; Gale, P. A. Angew. Chem. Int. Ed. 2001, 40, 486-5l6. (c) Bianch, A.; Bowman-James, K.; Garcia-España, E. Supromolecular Chemistry of Anions; Wiley-VCH: New York, 1997.

2. (a) Davis, A. P.; Joos, J.-B. Coord. Chem. Rev. 2003, 240, 143156. (b) Wallimann, P.; Marti, T.; Fürer, A.; Diederich, F. Chem. Rev, 1997, 97, 1567-1608.

3. Davis, A. P.; Gilmer, J. F,; Perry, J. J. Angew. Chem, Int. Ed. Engl. $1996,35,1312-1315$.

4. Davis, A. P.; Peny, J. J.; Williams, R. P. J. An. Chem. Soc. 1997, IJO, 1793-1794.

5. (a) Ayling, A. J.; Pérez-Payán, M. N.; Davis, A. P. J. Am. Chem Soc. 2001, 123, 12716-12717. (b) Ayling, A. J.; Broderick, S.; Clare, J. P.; Davis, A. P.; Pérez-Payán, M. N.; Lahtinen, M.; Nissinen. M. J.; Rissanen, K. Chem. Evir. J. 2002, 8, $2197-2203$. (c) Sisson, A. L.; Clare, J. P.; Taylor, L. K.; Channant, J. P. H.; Davis, A. P. Chent. Conmutm. 2003, 2246-2247.

6. Ghosh, S.; Choudhury, A. R.; Row, T. N. G.; Maitra, U. Org. Lett. 2005,7, I 44 I-I 444 .

7. Kim, K. S.; Kim, H.-S. Bull. Korean Chem. Soc. 2004, 25, 14II1413.

8. Shim, J. H.; Jeong. I. S.; Lee, M. H.; Hong, H. P.; On. J. H.; Kim, K. S.; Kim, H.-S.; Kim, B. H.; Cha, G. S.; Nam, H. Totanta 2004, $63,61-71$

9. Kim, K. S.; Kim, H.-S. Tetrahedron 2005, 61, 12366-12370.

10. Kim, K. S.; Cho, N. J.; Kim, H.-S. Bull. Korean Chem, Soc. 2006 , 27.739-743.

I1. Clare, J. P.; Ayling, A. J.; Joos, J.-B.; Sisson, A. L; Magro, G.; Pérez-Payán, M. N.; Lambert, T. N.; Shukla, R.; Smith, B. D.; Davis, A. P. J. Am. Chem. Soc. 2005, 127, 10739-10746.

12. Fielding, L. Tetrahedron 2000, 56, 6151-6170.

13. (a) Job, P. Compt. Rend, 1925, $180,928-930$. (b) Blanda, M. T.; Horner, J. H.; Newcomb, M. J. Org. Chem. 1989, 54, 4626-4636.

14. (a) Hynes, M. J. J. Chem. Soc. Dalton Trans. 1993, 311-325. (b) Connors, K. A. Binding Constants; Wiley: New York, 1987.

15. Kim, H.-S.; Choi, B.-S.; Kwon, K.-C.: Lee, S.-O.; Kwak, H. J.; Lee, C. H. Bioorg. Med.Chem, 2000, 8, 2059-2065.

16. Kim, J.; Raman, B.; Ahn, K. H. J. Org. Chem. 2006, 71, 38-45. 